\title{
野生牡丹的生存状况和保护
}

\author{
洪德元 $^{1^{*}}$ 周世良 ${ }^{1}$ 何兴金 ${ }^{2}$ 袁军辉 $^{3}$ 张延龙 $^{4}$ \\ 成仿云 ${ }^{5}$ 曾秀丽 6 王 雁 $^{7}$ 张秀新 $^{8}$ \\ 1 (中国科学院植物研究所系统与进化植物学国家重点实验室, 北京 100093) \\ 2 (四川大学生命科学学院, 成都 610064) \\ 3 (上海辰山植物园, 中国科学院上海辰山植物科学研究中心, 上海 201602) \\ 4 (西北农林科技大学风景园林艺术学院, 陕西杨凌 712100) \\ 5 (北京林业大学园林学院, 北京 100083) \\ 6 (西藏自治区农牧科学院蔬菜研究所, 拉萨 850030) \\ 7 (中国林业科学院林业研究所, 北京 100091) \\ 8 (中国农业科学院蔬菜花卉研究所, 北京 100081)
}

\begin{abstract}
摘要: 苟药属(Paeonia L.)的木本植物属于牡丹组(Paeonia sect. Moutan DC.), 共有9个野生物种和1个包含上千品 种的栽培种。所有野生牡丹都为中国特有, 是非同寻常的资源植物。1992年出版的《中国植物红皮书》收录了388 个保护类群, 野生牡丹就占了 4 个。本文回顾了野生牡丹保护的历史、调查和研究的经过、研究结果以及存在的问 题, 着重介绍了野生牡丹的生物学背景、分布和生境, 并就其濒危等级和保护措施提出了建议。根据我们的调查 和零星的资料, 凤丹 $(P$. ostii)和中原牡丹 $(P$. cathayana)都只剩单株, 亟待挽救; 紫斑牡丹(P. rockii)、卵叶牡丹 $(P$. $q$ qui)、四川牡丹 $(P$. decomposita) 和圆裂牡丹 $(P$. rotundiloba) 处于濒危状态; 大花黄牡丹 (P. ludlowii) 和矮牡丹 $(P$. jishanensis)应属于易危等级, 只有滇告丹(P. delavayi) 尚不在濒危之列。总结以往保护的进程, 我们强调, 如果没有 科学的物种划分, 保护单元不明确, 生态和生物学信息不够充实, 就难以制定科学的保护策略和可行的保护措施。 因此, 呼呼有关部门高度重视这一问题, 开展深入的野生牡丹现状的调查, 制定切实可行的保护策略, 并实行有 力的保护措施。
\end{abstract}

关键词：药药属; 野生牡丹; 保护; 物种划分

\section{Current status of wild tree peony species with special reference to con- servation}

De-Yuan Hong ${ }^{1 *}$, Shiliang Zhou ${ }^{1}$, Xingjin $\mathrm{He}^{2}$, Junhui Yuan ${ }^{3}$, Yanlong Zhang ${ }^{4}$, Fangyun Cheng ${ }^{5}$, Xiuli Zeng ${ }^{6}$, Yan Wang ${ }^{7}$, Xiuxin Zhang ${ }^{8}$

1 State Key Laboratory of Systematic and Evolutionary Botany, Institute of Botany, Chinese Academy of Sciences, Beijing 100093

2 College of Life Sciences, Sichuan University, Chengdu 610064

3 Shanghai Chenshan Botanical Garden, Shanghai Chenshan Plant Science Research Center, Chinese Academy of Sciences, Shanghai 201602

4 College of Landscape Architecture and Arts, Northwest A \& F University, Yangling, Shaanxi 712100

5 Landscape Architecture School, Beijing Forestry University, Beijing 100083

6 Institute of Vegetables of Tibet Academy, Agricultural and Animal Husbandry Sciences, Lhasa 850030

7 Institute of Forestry, Chinese Academy of Forestry, Beijing 100091

8 Institute of Vegetables and Flowers, Chinese Academy of Agricultural Sciences, Beijing 100081

Abstract: The section Moutan DC. of Paeonia L. contains nine wild species of tree peonies and one cultivated species comprising hundreds of cultivars. All wild species are endemic to China, and are highly valuable resources. The China Plant Red Data Book published in 1992 includes 388 conservation units, of which four are tree peonies. The present article briefly reviews the history of field surveys, investigations, and con-

收稿日期: 2017-04-26; 接受日期: 2017-06-28

* 通讯作者 Author for correspondence. E-mail: hongdy@ibcas.ac.cn 
servation of wild tree peonies, as well as preliminary results, and finally proposes questions and suggestions for future work. The article focuses the biological background of wild tree peonies, their distribution and habitats, and proposes suggestions for endangered ranks and conservation strategies. Based on our survey and incomplete data, we consider that $P$. ostii and $P$. cathayana each has only one individual, and thus effective conservation measures should be taken for them immediately; P. rockii, P. qiui, P. decomposita and P. rotundiloba are endangered; P. ludlowii and P. jishanensis are vulnerable, and of the nine wild species of tree peonies, unfortunately, only $P$. delavayi is classified as a healthy species. We emphasize that if species delimitation is not rational, conservation units are not clearly defined, and ecological and biological information is inadequate, it will be impossible to work out a scientific conservation strategy and practical conservation measures. Lastly, the article appeals to relevant agencies to pay attention to conservation of wild tree peonies, to provide funds for conducting intensive surveys examining the present situation of wild tree peonies, and subsequently to formulate a rational strategy and feasible measures for conserving precious wild tree peonies.

Key words: Paeonia; wild tree peony species; conservation; species delimitation

\section{1 野生牡丹保护的意义}

“唯有牡丹真国色，花开时节动京城”的诗句生 动描述了唐朝时期人们喜爱牡丹花的狂热景象。如 今，栽培牡丹更是传遍世界，特别是北半球，许多 发达国家都有牡丹/药药协会, 人们培育牡丹新品 种的热情越来越高。我国栽培牡丹的传统品种是由 产于中原地区的 5 个野生种人为汇集在庭院中经自 然杂交后选育而来的(Zhou et al, 2014)。显然, 野生 牡丹是培育牡丹新品种的宝库。

苟药科仅有苟药属(Paeonia L.) 1属。苟药科具 有一些独特的特征, 这使它的分类地位不断攀升, 从隶属于毛茛科的属到族、苟药科、苟药亚目、苟 药目、苟药超目, 直至药药亚纲。苟药科在被子植 物中十分孤立, 其系统位置一直存在激烈争论。20 世纪90年代以前, 一派学者认为它与毛茛类(包括 毛茛科和白根葵科)近缘(Takhtajan, 1987, 1997), 而 另一派则认为第伦桃类(第伦桃科和燧体木科)是它 的近亲(Cronquist, 1981)。分子系统学问世后, 被子 植物的系统发生分析颠覆了上述两派的观点, 各种 分子树都出人意料: 苟药科居然与虎耳草科、景天 科、小二仙草科、金缕梅科、交让木科、连香树科等 构成一大支，即虎耳草目(Chase et al, 1993; APG, 1998; APG II, 2003; APG III, 2009; APG IV, 2016)。但是在虎 耳草目中苟药科究竟和哪类植物最近, 不同分析 方法得出了不同结果(Jian et al, 2008)。因此苟药科 的系统位置至今仍然是一个悬而未决的问题。

苟药属中所有木本类群都属于牡丹组(Paeonia sect. Moutan DC.)。尽管野生牡丹中有两个物种分布 于西藏东南部和云南西北部, 但其分布区都没有超 越中国国界，因此所有野生牡丹都为中国特有。
牡丹有很高的经济价值，除了以“花中之王”供 观赏之外，其根皮可作中药(称“丹皮”), 被列入中 国药典, 为复方中的常用药材之一。牡丹籽油富含 不饱和脂肪酸, 尤其是 $\alpha$-亚麻酸, 是很有发展前途 的健康食用油之一。

\section{2 野生牡丹保护实践的教训}

野生牡丹作为牡丹遗传资源的宝库，自唐朝以 来已经经受了广泛的挖掘，遭到严重的破坏，目前 至少有两个物种已野外灭绝或濒临灭绝。《中国植 物红皮书: 稀有濒危植物》(第一册)(傅立国和金鉴 明，1992)共收集了388个保护单元(种和变种), 其中 野生牡丹就有4个, 分别是黄牡丹[Paeonia delavayi Franch. var. lutea (Delavay ex Franch.) Finet \& Gagnep.]、紫斑牡丹 $[P$. suffruticosa Andr. papaveracea (Andr.) Kerner]、矮牡丹 (P. suffruticosa Andr. var. spontanea Rehd.)和四川牡丹(P. szechuanica Fang)。 遗憾的是，由于当时条件的限制，这4个保护单元 的拉丁学名没有一个是正确的, 而且物种划分和保 护单元的确定亦缺乏科学性，物种信息尤其欠缺 (洪德元和潘开玉, 1999; Hong, 2010, 2011b)。四川牡 丹的正确学名应为Paeonia decomposita Hand.Mazz., 矮牡丹应是Paeonia jishanensis T. Hong \& W. Z. Zhao, 紫斑牡丹应是Paeonia rockii (S. G. Haw \& Lauener) T. Hong \& J. J. Li ex D. Y. Hong。而《中国 植物红皮书》中用于紫斑牡丹的学名P. suffruticosa Andr. var. papaveracea Andrews实为栽培牡丹的一 个品种名称。“黄牡丹”这一保护单元从学名到科学 内容都是错的。按《中国植物红皮书》中的描述和 分布图, 它应是滇牡丹(Paeonia delavayi Franch.)的 
黄花类型, 广泛分布于四川西部、云南北部和西藏 东南部(西至林芝)。我们的深入调查发现, 在这一牡 丹中花色不应作为分类的依据(Hong, 1997b; Hong et al, 1998; Hong, 2010, 2011b)。西藏隆子、米林等 地开黄花的野生牡丹其实是区别分明的独立物种 大花黄牡丹 (P. ludlowii (Stern \& G. Taylor) D. Y. Hong), 是分布很局限十分珍贵的一种野生生丹。这 就造成了应该保护的大花黄牡丹混在了常见种中, 遭受了几乎灭绝性的破坏, 而不濒危的物种却被当 作濒危物种保护, 费钱、费力, 劳而无功。这个案 例警醒我们, 物种的科学划分是确定保护单元、有 效保护濒危物种的前提。

\section{3 野生牡丹的物种分布}

《中国植物志》 27 卷中的蔦药属编写之时, 中 国植物分类学研究的条件还很差, 文献不全, 绝大 多数模式标本在国外, 国内各标本馆所存野生牡丹 标本胗塞无几。植物分类学家认为牡丹是园林植物, 园艺学家会关注其分类问题, 而园艺学家又认为牡 丹分类是植物分类学家的事, 从而造成了牡丹分类 两不管的境况。在这样的窘境下编写完成的《中国 植物志》 27 卷中的药药属, 难以保证物种划分的科 学性和物种名称的正确性, 而1992年出版的《中国
植物红皮书》基本上沿用了植物志中的分类处理， 所确定的野生生丹保护类群缺乏科学基础。

1993年我们意识到这一问题, 在美国国家地 理学会 5 个基金的连续支持下，从1995年开始对除 非洲西北部的摩洛哥和阿尔及利亚以外的苻药属 的整个分布区(从西班牙至日本及北美西部)进行了 10 年的考察, 期间或之后又查阅了国内外 65 个植 物标本馆的全部药药属标本，包括所有模式标本。 我们通过研究澄清了世界芳药属的物种和物种关 系, 确认全属有 34 个物种, 其中牡丹组有 9 个野生 种和1个栽培的杂交种(Hong, 2010, 2011b)。下文的 检索表用以区分或鉴别这 9 个野生牡丹物种。此后, 我们利用转录组方法获取 4,910 个候选基因, 从中 篮选出 25 个单拷贝核基因, 利用 37 个野生生丹样 本构建了高分辨率的系统发生树(Zhou et al, 2014)。 结果显示, 野生牡丹包含 9 个物种, 与依据形态分 析得出的结果高度吻合。接着我们选用1949年以前 在中国育成的 47 个牡丹传统栽培品种, 探讨它们 与野生牡丹的关系, 发现中原地区的 5 个野生种参 与了传统栽培品种的形成, 其中 3 个野生种既作了 父本又作了母本(Zhou et al, 2014)。西南地区分布 的 4 个野生种, 如大花黄牡丹, 未参与中国传统栽 培品种的形成。

\section{野生牡丹分种检索表}

1a. 花通常2-4朵集成聚伞花序，多少下垂; 花盘肉质，仅包心皮基部; 心皮无毛 肉质花盘亚组subsect. Delavayanae Stern

2a. 心皮通常2-5枚, 偶至7枚; 果长不足 $4 \mathrm{~cm}$, 直径 $1.5 \mathrm{~cm}$; 花瓣、花丝和柱头常不为纯黄色

1. 滇牡丹P. delavayi Franch. (云南中部和西北部、四川西部、西藏东南部)。

$2 \mathrm{~b}$. 心皮几乎总是单枚, 稀2枚; 果长4.7-7 cm, 直径2 $-3.3 \mathrm{~cm}$; 花瓣、花丝和柱头总是纯黄色.

..2. 大花黄牡丹P. ludlowii (Stern \& G. Taylor) D. Y. Hong (西藏米林、隆子)。

1b. 花单朵, 上举; 花盘革质, 全包心皮, 少数仅包心皮下半部; 心皮被毛或无毛.

革质花盘亚组subsect. Vaginatae Stern

3a. 心皮无毛, 2-5枚; 花盘在花期包心皮下半部或至花柱基部; 下部叶多回复出, 小叶19-71, 全 部分裂。

4a. 心皮几乎总是5, 稀3或4枚; 花盘开花时仅包心皮下半部; 小叶 35-71枚, 椭圆形至狭菱 形……四川牡丹P. decomposita Hand.-Mazz. (四川大渡河流域: 马尔康、金川、丹巴、康定) 4b. 心皮通常3, 较少4或2, 更少5枚; 花盘花期包心皮至花柱基部; 小叶通常 25-37, 少至 19, 多至49枚; 菱形至近圆形.

圆裂牡丹P. rotundiloba (D. Y. Hong) D. Y. Hong

(四川岷江流域: 黑水、松潘、茂县、汶川、理县)。

3b. 心皮被绵毛或线毛, 5枚, 稀至7枚; 花盘在花期全包心皮; 下部叶二回三出、二回三出羽状或 三出二回羽状，小叶通常少于20(稀少达到33)，如多于20，则至少有部分小叶全缘。 
5a. 下部叶具9枚小叶; 小叶卵形, 卵圆形, 仅顶生小叶3裂, 叶片上面常淡紫色; 花瓣基部常 带淡红色斑块

......㧮叶牡丹P. qiui Y. L. Pei \& D. Y. Hong (湖北神农架、保康; 陕西旬阳; 河南西峡？）。

$5 b$. 下部叶的小叶数多于 9 , 如 9 则小叶大多分裂; 叶片上面绿色; 花瓣无斑块或基部有深紫色 斑块。

6a. 下部叶具11-33枚小叶; 小叶通常卵形至披针形，大多全缘，少卵圆形而大多分裂。

7a. 下部叶具11-15枚小叶; 小叶卯形至卵状披针形，大多全缘; 花瓣白色，稀浅粉色， 无斑块. 凤丹P. ostii T. Hong \& J. X. Zhang (安徽巢湖; 河南卢氏? 西峡? )。

7b. 下部叶具17-33枚小叶; 小叶披针形或卵状披针形, 多数全缘, 或卵形至卵圆形, 多数分裂; 花瓣白色, 少红色, 基部总有一个深紫色大斑块

.紫斑牡丹P. rockii (S. G. Haw \& Lauener) T. Hong \& J. J. Li ex D. Y. Hong (湖北西部、河南西部、陕西秦岭, 北至志丹、甘肃东南部、四川北部)。

6b. 下部叶具9枚小叶(P. jishanensis中偶见11或15枚); 小叶卵形或卵圆形，多数或全部 分裂。

$8 \mathrm{a}$. 小叶卵形，顶生小叶 3 或 5 裂，并具 1 至数枚浅裂片，侧生小叶大多 2 或 3 裂，较少全 缘，裂片顶端急尖; 叶片背面无毛; 墓片顶端都有尾尖或突尖

.中原牡丹P. cathayana D. Y. Hong \& K. Y. Pan(河南嵩县?)

$8 \mathrm{~b}$. 小叶卵圆形，全部3裂; 裂片浅裂，顶端急尖至圆; 叶片背面被长柔毛; 花萼顶端 全部圆钝 .矮牡丹P. jishanensis T. Hong \& W. Z. Zha (山西稷山和永济、河南济源、陕西华阴和铜川)。

\section{4 野生牡丹的生存现状}

\section{(1)中原牡丹}

Paeonia cathayana D. Y. Hong \& K. Y. Pan, Acta Phytotax. Sin. 45(3): 286. fig. 2. 2007.

中原生丹的发现过程是一个小故事。1994年春, 洪德元和潘开玉在河南农业大学王遂义、叶永忠两 位教授的支持和帮助下, 赴河南嵩县木植街乡考察 新发表的杨山牡丹(Paeonia ostii T. Hong \& J. X. Zhang)的野生居群, 未果。他们得知原为乡村小学 老师的杨惠芳先生的宅旁种有一株野生牡丹, 于是 前往拜访。杨先生说这株牡丹是他1961年从附近山 上挖来的。因时间关系, 这当时并未引起他们的足 够重视。1995年后洪德元和潘开玉开始把主要精力 投入到世界苟药属的专著性研究上, 这株牡丹遂引 起他们的关注。1997年, 河南农业大学的叶永忠教 授、洪德元和他的博士研究生俸宇星再次拜访了杨 先生。除了拍照片(Hong, 2011b)、采集1个枝条制作 标本(就是Paeonia cathayana的模式标本)外, 还雇 了几位老乡分成3组上山寻找这种野生牡丹, 但搜 寻了两天无果而终。
我们以 25 个单拷贝核基因建立的系统发生树 显示, 中原牡丹与凤丹存在密切关系, 但遗传分化 明显(Zhou et al, 2014)。从形态上看(Hong \& Pan, 2007), 它是一个好种, 尽管至今没有发现中原牡丹 真正的野生居群, 但在大量传统牡丹品种中存在其 “血统”(Zhou et al, 2014)。我们推断中原牡丹由于花 红色及历史上的牡丹崇拜而遭过度采挖已野外灭 绝。考虑到中原牡丹在形态和遗传上的独特性, 并 在历史上曾作为母本和父本参与品种形成, 必须承 认这个物种确实存在过。

\section{(2)四川牡丹}

Paeonia decomposita Hand.-Mazz., Acta Horti Gothob. 13: 39. 1930.

异名: Paeonia szechuanica W. P. Fang, Acta Phytotax. Sin. 7: 315. pl. 61-1. 1958.

Hong (2010)在Peonies of the World: Taxonomy and Phytogeography一书中认为这个物种分布于大 渡河流域和峮江流域, 被海拔超过 $4,000 \mathrm{~m}$ 的邛崃 山和夹金山分割成两个亚种。后经深入的形态学研 究和系统发生分析, 发现邛崃山和夹金山东西两侧 的居群分属两个独立的物种, 即 $P$. decomposita 
Hand.-Mazz. 和 $P$. rotundiloba (D. Y. Hong) D. Y. Hong (Hong, 2011a)。这一修正收录在Peonies of the World: Polymorphism and Diversity (Hong, 2011b)。

四川牡丹以学名Paeonia szechuanica W. P. Fang被列入《中国植物红皮书》(傅立国和金鉴明, 1992)。书中的地图(p. 537)显示，该种局限分布于四 川北部的大渡河流域, 且仅有 3 个分布点, 即马尔康 镇、松岗和金川的马尔帮。后来的调查发现, 该种分 布于大渡河流域的 4 个县, 有 13 个点的记录: 马尔康 (阿底村、县城附近南北两坡、松岗、卓克基、脚木 足)、丹巴(东谷乡沙冲、革什扎乡)、金川(马尔帮乡、 沙尔乡、曾达乡和绰斯甲、万林)和康定(大河沟村)。 四川牡丹的水平分布从北纬 $30^{\circ}$ 至 $32^{\circ}$, 从东经 $101^{\circ} 30^{\prime}$ 至 $102^{\circ} 30^{\prime}$ (图 1); 海拔分布从 $2,050 \mathrm{~m}$ 至 $3,100 \mathrm{~m}$, 是一个分布很狭域的物种。它生长于多石 的山坡和悬崖上的灌丛、幼龄的次生林或稀疏的柏 树林(图2a,b)。这个种虽然分布狭域，生态幅也不宽， 但根据我们的调查、标本记录和对当地老乡的访问, 其居群数至少在 10 个以上, 个体数估计应以千计, 有些地方还局部常见(附录 $1 \mathrm{a})$ 。但最近何兴金等(未 发表资料)对 8 个居群的调查发现其个体数已不足 500 , 生存状况不容乐观。四川牡丹的最适生境是阳 坡的稀疏灌从, 这种生境下植株开花多, 结实率高 (图2c, d, e); 而在次生林和高度超过 $2 \mathrm{~m}$ 的灌从中, 则很少开花, 结实率低。

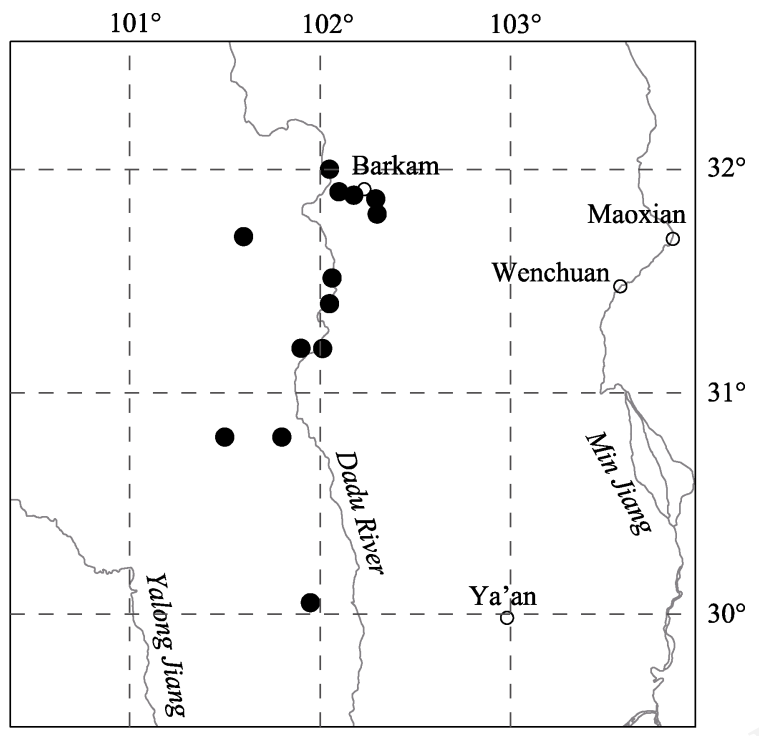

图1 四川牡丹野生居群的分布

Fig. 1 Distribution of wild populations of Paeonia decomposita Hand.-Mazz.

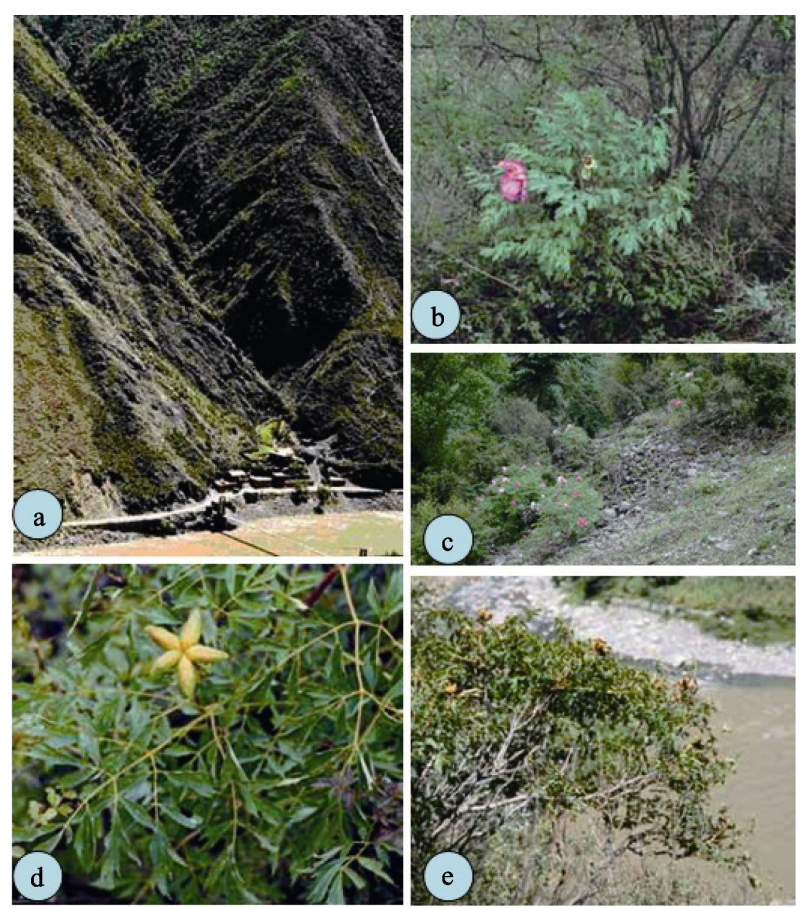

图2 四川牡丹的生境及结实情况。a, b: 生境, 灌丛或疏林; c-e, 在开阔的灌丛或林缘中结实率较高。

Fig. 2 Habitats and fruits of Paeonia decomposita Hand.Mazz. a, b, Habitats, thickets of sparse forests; c, d, e, Open thickets of edges of forests, where plants have high fecundity.

基于ISSR的遗传多样性分析表明，四川牡丹的 遗传多样性水平不高, 居群间基因流水平较低 $\left(\mathrm{N}_{\mathrm{m}}=\right.$ 0.9065 , 何兴金(未发表资料)。这很可能是因为其居 群小、居群间空间距离大而使居群间传粉受限所致, 加之种子大且非肉质而不被鸟类散布，导致居群间 基因流有限。

根据分布、生物学特性和生存现状, 我们认为 四川牡丹处于濒危( $\mathrm{EN})$ 状态，如果不严格控制采挖， 并对环境作适当的人为干预来维持或创造开阔的 灌丛生境, 该种难以逃脱绝灭的命运。

\section{(3)滇牡丹}

Paeonia delavayi Franch., Bull. Soc. Bot. France 33: 382.1886.

异名: Paeonia lutea Delavay ex Franch.; P. potaninii Kom.; P. trollioides Stapf ex Stern; P. delavayi var. lutea (Delavay ex Franch.) Finet \& Gagnep.

这个物种的范畴直到1998年(Hong et al, 1998) 才得以确认，之前曾被认为由 4 个物种组成(Stern, 1931, 1946); 在《中国植物志》中则被作为 1 个种的 3 个变种处理(潘开玉, 1979)。 
滇牡丹的分布范围相当大，包括云南的中部和 西北部, 四川的西部和西南部, 以及西藏的东南 部, 从北纬 $24^{\circ}$ 至 $32^{\circ}$, 从东经 $94^{\circ}$ 至 $104^{\circ}$, 是 9 种野 生牡丹中分布范围最广的。在垂直分布上则从海拔 $1,850 \mathrm{~m}$ (四川木里的罗波)至4,000 $\mathrm{m}$ (四川稻城的东 义), 高差达 $2,150 \mathrm{~m}$, 也是牡丹各野生种中垂直分 布范围最大的。

滇牡丹在多种生境中出现, 不仅在灌丛和疏林 中常见, 在相当茂密的云南松(Pinus yunnanensis)高山栎(Quercus semecarpifolia)林中(云南宁蒗县等), 甚至在云杉(Picea)原始林中也能见到(云南丽江云 杉坪)(图3a, b, c, d)。其生态幅相当宽, 这可能得益 于它纺锤状加粗的根(图3e) 既能拒水又能储存营

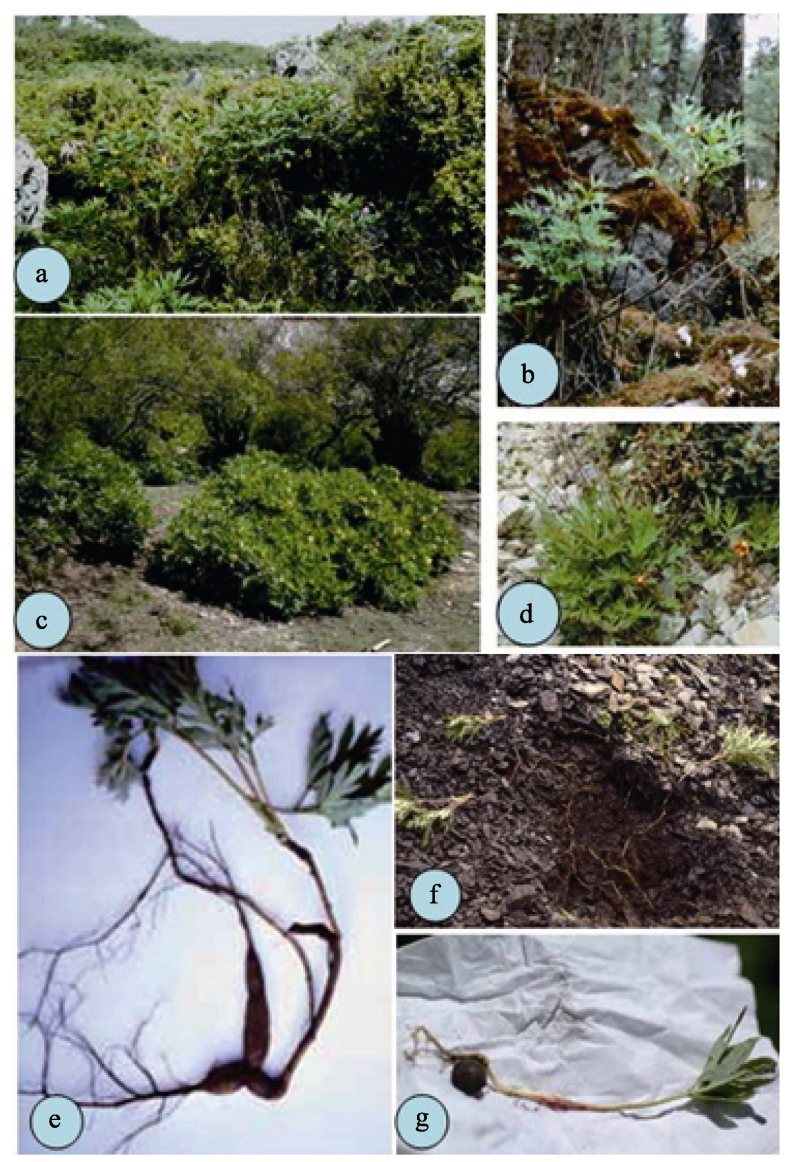

图3 滇牡丹生境(a-d)、地下部分形态(e, f)和实生苗(g)。a: 昆明呈贡, 高灌丛; b: 云南丽江云杉坪, 针叶林; c: 西藏林 芝八一镇, 林缘开阔地; d: 云南香格里拉, 稀疏灌丛; e: 纺 锤根和地下茎; f: 地下茎(四川雅江尼日乡); g: 实生苗。

Fig. 3 Paeonia delavayi Franch. a-d, Habitats; a, Chenggong, Kunming, tall thickets; b, Yunshanping of Lijiang, Yunnan, coniferous forest; c, Bayi Town, Nyingchi, Tibet, open edges of forests; d, Shanggri-la, Yunnan, sparse thickets; e, Fusiform roots and rhizomes; f, Rhizomes (Niri Township of Yajiang, Sichuan); g, A seedling.
养。这个种不仅有很多居群，而且有的居群很大。 如丽江干海子居群, 其范围相当大, 植株(可能包括 许多无性系)无数。特别是香格里拉县的格咱乡, 在 香格里拉至四川乡城的公路两边, 一个居群绵延 $10 \mathrm{~km}$, 植株(包括无性系)不计其数。

滇牡丹保持着无性繁殖和种子繁殖两种生殖 方式(图3e, f, g), 至于二者所占比例目前还不得而 知。总体看来, 地下茎延伸的无性繁殖看似更占优 势, 在云南香格里拉的哈那村居群(图3e)和格咱乡 居群、丽江的干海子居群、四川雅江的尼日乡居群 (图3f)都有记录。这种繁殖方式显然有利于居群的 扩张、逃避人为挖掘和其他干扰。

滇牡丹是一个形态极其多变的物种(Hong et al, 1998; Haw, 2001, 2001a)。叶裂片数目在居群内从 17 到 312 , 叶裂片宽度从 $0.5 \mathrm{~cm}$ 到 $4.5 \mathrm{~cm}$ 。花瓣颜色从 黄中带绿(昆明西山)到黄色(各处都有)、黄色而基部 带棕色至紫色的斑块(几乎各处均有)、白色(云南德 钦和香格里拉)、粉色(云南丽江、香格里拉等地)、 红色(四川木里、雅江和盐源, 云南丽江、香格里拉 等地), 至深紫色(云南丽江和香格里拉), 甚至在云 南香格里拉的格咱乡和哈那村以及丽江的干海子, 上述各种颜色都能见到。在香格里拉哈那村附近一 个居群内竟有 125 种花色变异, 说明这个物种具有 丰富的形态多样性。

由此可见, 滇牡丹不属于濒危物种。但是, 滇 牡丹叶形变异大, 特别是花色的变异丰富, 是培育 新品种的珍贵资源, 应在保护的前提下加以利用。

\section{(4)矮牡丹(稷山牡丹)}

Paeonia jishanensis T. Hong \& W. Z. Zhao, Bull. Bot. Res. Harbin 12 (3): 225. fig. 2. 1992.

异名: Paeonia spontanea (Rehd.) T. Hong \& W. Z. Zhao (1994); Paeonia suffruticosa Andrews var. spontanea Rehder (1920).

矮牡丹的模式标本采自延安城西约 $25 \mathrm{~km}$ 的万 花山。山上崔府君庙里有一个古老的牡丹园, 这个 园的历史有多久当地老乡也不十分清楚。在园内一 个小凹沟内及其旁边有多株矮牡丹, 它们多有雄荵 瓣化现象。我们认为它们应是很多年前从别处移栽 的。洪涛等把山西稷山无瓣化雄荵的野生矮牡丹作 为新种发表, 即Paeonia jishanensis T. Hong \& W. Z. Zhao。两年后他们又把P. suffruticosa var. spontanea 
Rehder 提升为物种等级, 即 Paeonia spontanea (Rehder) T. Hong \& W. Z. Zhao。

依据我们的野外调查、标本室标本和文献记载, 矮牡丹自然居群分布于 $34^{\circ} 25^{\prime}-35^{\circ} 42^{\prime} \mathrm{N} 、 110^{\circ}-$ $112^{\circ} 15^{\prime} \mathrm{E}$, 水平分布范围很小, 局限于山西、河南 和陕西三省相邻地区(图4)。主要见于山西吕梁山南 端稷山县西社乡的马家沟和中条山西端永济县的 雪花山, 河南济源县黄楝树林场, 以及陕西华阴县 和铜川。而延安万花山牡丹园中的矮牡丹不太可能 是自然居群。

矮牡丹的垂直分布海拔 $970 \mathrm{~m}$ (永济水峪口村) 至 $1,700 \mathrm{~m}$ (稷山马家沟), 高差仅 $730 \mathrm{~m}$, 分布范围 很小, 生态幅也狭小。它出现的群落是灌从和稀疏 的落叶阔叶林(图5a, b, c)。根据Zhou (1999)对稷山 居群的观察和统计, 其结实率很低。罗毅波等(1998) 对稷山和永济两个自然居群的观察得出类似结果。 我们在考察中未发现实生苗, 但根出条现象很普遍 (图 $5 \mathrm{~d}$, 附录 $1 \mathrm{~b}$ )，成仿云等的观察结果(未发表资料) 与此相似。该种为兼性营养繁殖, 且显然以无性繁 殖为主。可能正是这一繁殖特性, 使其逃脱了 1960 年前后因大量收购丹皮而被挖尽的厄运。

分析发现, 矮告丹居群内遗传多样性水平不高, 居群间分化大。这与其生殖特性和现今的零星分布 特点相吻合。因而对矮牡丹的保护策略应是保护所 有居群, 严禁采挖, 恢复或创造其最适生境(灌从或

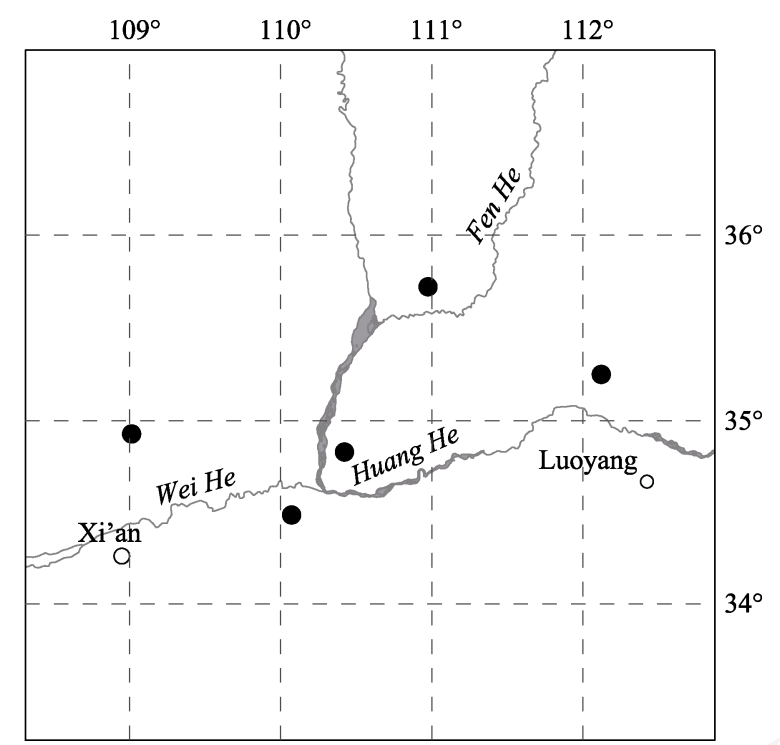

图4 矮牡丹野生居群的分布

Fig. 4 Distribution of wild populations of Paeonia jishanensis T. Hong \& W. Z. Zhao

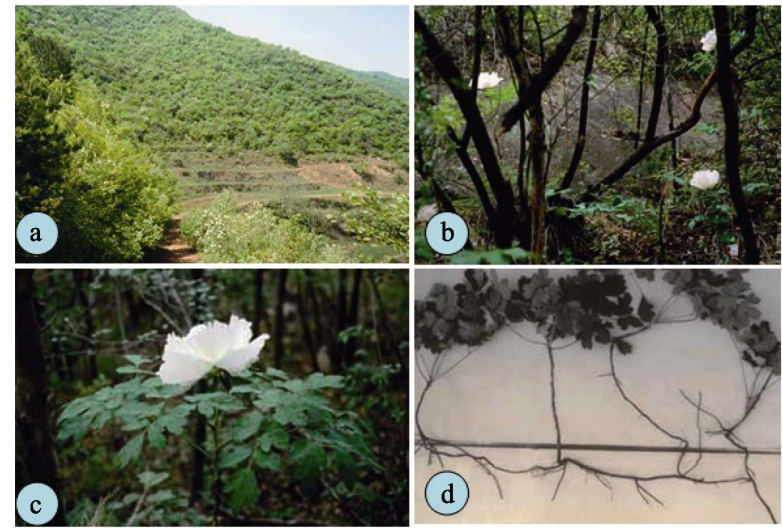

图5 矮牡丹的生境和萌生苗。a, b, c: 生境, 灌丛或稀疏的 落叶阔叶林; d: 无性繁殖(萌生苗)。

Fig. 5 Paeonia jishanensis T. Hong \& W. Z. Zhao. a, b, c, Habitats, thickets or sparse deciduous broad-leaved forest; $d$, Vegetative reproduction.

稀疏落叶林)。鉴于矮牡丹虽然居群已经很少，但居 群内个体尚多, 且具无性繁殖能力, 我们认为该物 种应为易危等级(VU)。

\section{(5)大花黄牡丹}

Paeonia ludlowii (Stern \& G. Taylor) D. Y. Hong, Novon 7(2): 157. figs. 1, 2. 1997.

异名: Paeonia lutea Delavay ex Franch. var. ludlowii Stern \& G. Taylor, J. Roy. Hort. Soc. 76: 217. 1951; P. delavayi Franch. var. lutea auct. non Delavay ex Franch., p. p.

大花黄牡丹因其花黄色，在1997年之前被英国 人 Stern和 Taylor (1951)处理为P. Iutea的一个变种, 而在中国则曾把它与滇牡丹(P. delavayi)中相当广布 的、花黄色的变种即“黄牡丹”(P. delavayi var. lutea (Delavay ex Franch.) Finet \& Gagnep)混在一起。《中 国植物红皮书》(傅立国和金鉴明，1992)也就把大花 黄牡丹混在“黄牡丹”中。由于“黄牡丹”分布范围广, 且相当常见, 并不濒危, 因此大花黄牡丹的生存状 况一直未引起人们的重视。直到1996年我们在西藏 东南部考察时，发现当地所称的“大花黄牡丹”不同 于其他地区的“黄牡丹”, 是一个区别分明的独立物 种Paeonia ludlowii (Stern \& G. Taylor) D. Y. Hong。遗 憾的是, 这样一个特有物种遭到了近乎毁灭性的破 坏(图6a, b)。

我们的调查和研究表明, 大花黄牡丹尚存 6 个 居群, 一半在米林县, 一半在隆子县。现已查明, 林 芝东久乡曲尼玛村的大花黄牡丹是移栽的。 
这个物种分布很狭域, 从北纬 $28^{\circ} 26^{\prime}$ 至 $29^{\circ} 34^{\prime}$, 东经 $92^{\circ} 50^{\prime}$ 至 $94^{\circ} 40^{\prime}$, 跨纬度 $1^{\circ} 08^{\prime}$, 经度 $1^{\circ} 50^{\prime}$ (图7)。 海拔的高差亦极小, 从 $2,920 \mathrm{~m}$ 至 $3,320 \mathrm{~m}$, 跨度仅 $400 \mathrm{~m}$ 。该物种生长的土壤基质为花岗岩, 多生长 于疏林和灌从中(图6c, d), 郁蔽的森林中未见其踪 影。这一物种完全依赖种子繁殖, 结实率高, 出苗率 也高(图6 e-h), 在大多数居群中都发现有大量实生 苗(附录1c)。我们在南伊沟一株大的植株下面积仅约 $1 \mathrm{~m}^{2}$ 的范围内就发现有上百株小苗。

初步调查显示, 大花黄告丹只要有适宜的生境, 即开阔的疏林和灌从, 就能繁衍后代。因此可考虑 把大花黄牡丹定为易危 $(\mathrm{VU})$ 等级。对它的保护策略

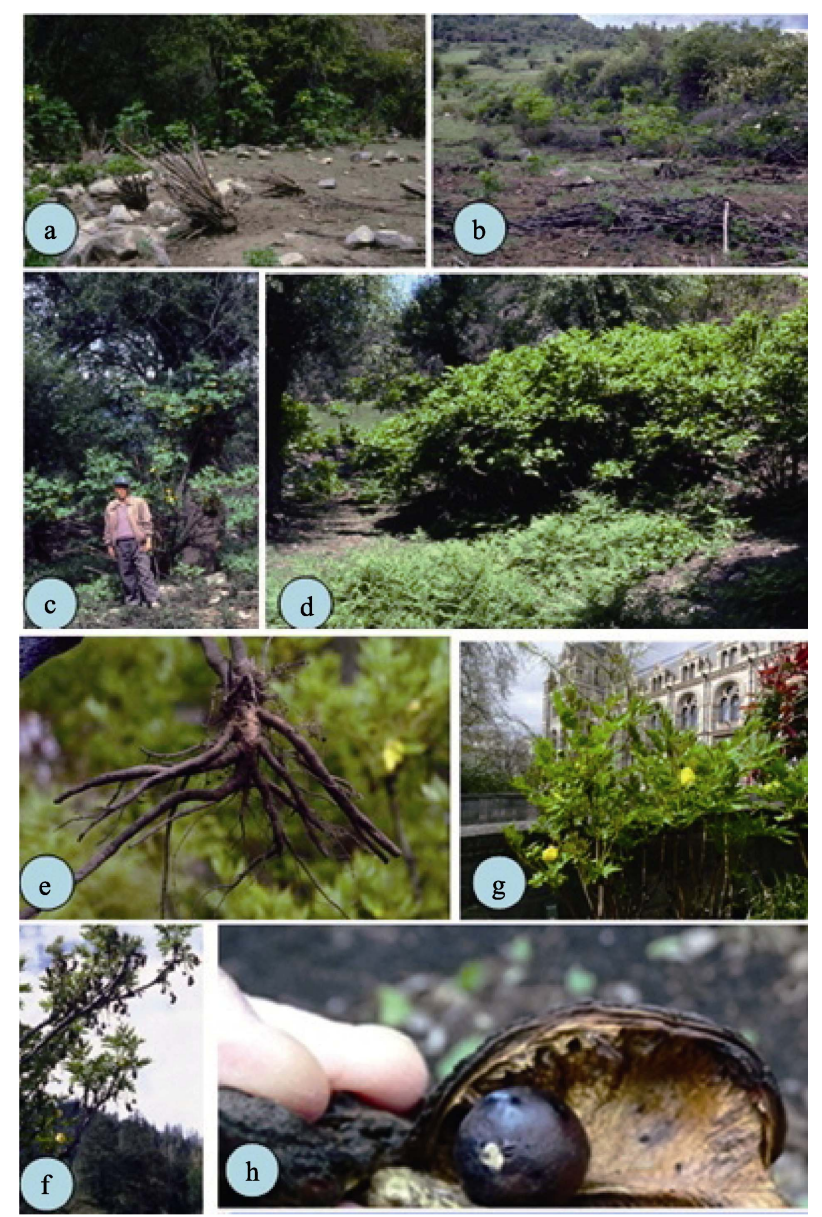

图6 大花黄牡丹。a, b: 乱采滥挖造成的惨象和适宜生境; c, d: 林缘的环境; e: 根象一般灌木, 无营养繁殖迹象; f: 下 垂的蓇菅果挂满枝; g: 英国自然博物馆大门两侧的大花黄 牡丹; h: 英国皇家邱植物园中繁殖的大花黄牡丹种子。

Fig. 6 Paeonia ludlowii (Stern \& G. Taylor) D. Y. Hong. a, b, Suitable habitats and illegal digging; c, d, Environment at edges of forest; e, A root like that of common shrub; f, Numerous pedent follicles; g, P. ludlowii in the front of Natural History Museum, London; h, A seed of P. ludlowii in the Royal Botanic Gadens, Kew.

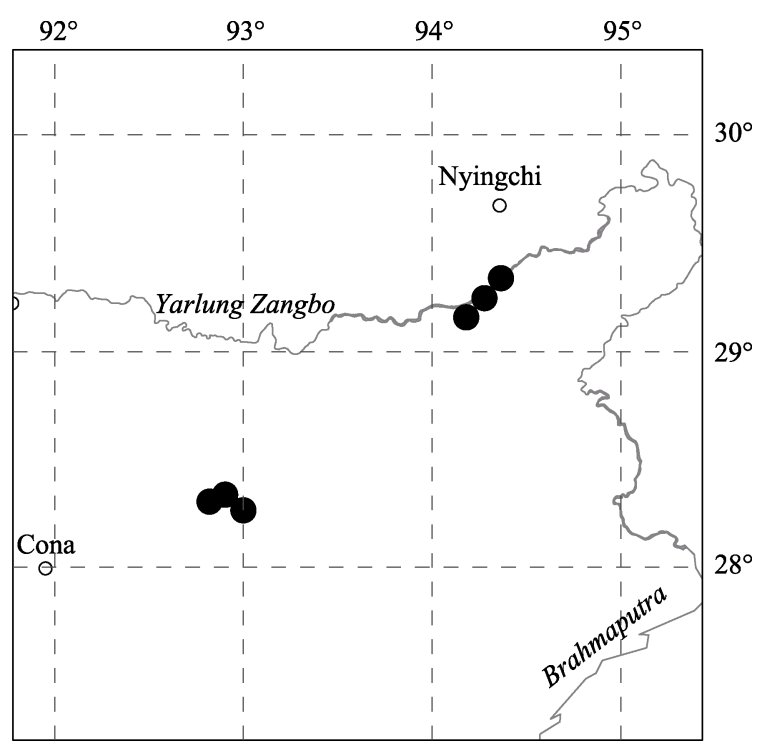

图7 大花黄牡丹野生居群的分布

Fig. 7 Distribution of wild populations of Paeonia ludlowii (Stern \& G. Taylor) D. Y. Hong

是严格控制采挖, 适度进行人为干扰以创造其适生 生境。至于大花黄牡丹为何如此狭域分布, 仍是一 个有待研究的问题。

\section{(6)风丹(杨山牡丹)}

Paeonia ostii T. Hong \& J. X. Zhang, Bull. Bot. Res. Harbin 12(3): 223. fig. 1, 1992.

异名: Paeonia suffruticosa Andrews subsp. yinpingmudan D. Y. Hong, K. Y. Pan \& Z. W. Xie, Acta Phytotax. Sin. 36(6): 519. fig. 2, 1998.

凤丹作为著名中药“丹皮”的原植物被广泛栽 培。现已澄清, 它与普遍栽培且被称为“花中之王” 的牡丹 $($ Paeonia $\times$ suffruticosa Andrews)不同, 是一 个独立的物种。但是凤丹的野生状况如何? 这已经 成了一个谜。洪涛和张家勋在发表新种(P. ostii)时称 之为“杨山牡丹”。文中说，模式标本采自“郑州航空 业管理学院珍稀树木园栽培”, 而原植物引自河南 “嵩县, 杨山, 海拔 $1,200 \mathrm{~m}$, 生于山坡灌从中。我们 于1993年和1997年两次赴嵩县杨山漫山遍野寻找 该种, 未果。那儿确有“杨山牡丹”, 且并不鲜见, 但 都在地边和宅旁。

邱均专1988年在河南“西峡海拔 $1,600 \mathrm{~m}$ 的林 中”采到 1 份凤丹标本, 可惜他未指出具体山头。 1998年, 潘开玉、洪德元和河南农业大学的王遂义 教授、北京大学的饶广远教授去河南考察, 在西峡 二郎坪只发现了草药药(P. obovata)。接着他们又去 
卢氏县狮子坪乡考察，官坡乡蔡家村陈家院小村的 陈远超展示了一个带花的枝条, 就是凤丹。2002年4 月, 潘开玉、张宏耀和洪德元专程赴河南卢氏县拜 访陈远超时, 他的儿子陈相枢介绍说他家门前种的 两株牡丹是 1999 年从附近山上挖来的, 但长势不 佳。一行人再次上山寻找但仍未找到这一物种, 并 继续在狮子坪和杨木场一带搜寻。在老乡的带领下, 他们翻山越岭, 登上了玉皇顶(豫、陕交界处, 海拔 $2,040 \mathrm{~m})$, 亦无收获。

2007年河南新乡一位大学老师说辉县关山上 可能有野生风丹, 在他的引导下我们在七里坡(海 拔约 $900 \mathrm{~m}$ ) 终于找到了生长在撂荒多年的荒地及其 边缘的凤丹。但在附近山上林中和灌从中未发现任 何牡丹，只发现了当地称为“红牡丹”的草药药。

确切无疑的野生状态下的凤丹唯有安徽巢湖 银屏山悬崖上的那株“银屏牡丹”, 悬崖离地面约 40 $\mathrm{m}$ 。中国科学院植物研究所李敏和马欣堂拍摄的照 片(Hong, 2011b)清晰显示, 其茎下部叶为三出羽状 复叶, 小叶11-15枚, 侧生小叶不裂; 花盘革质, 红 色; 心皮5枚。

综合上述，野生凤丹仅巢湖1株(图8)。罗毅波等 (1998)的研究表明, 牡丹为异交繁育植物, 因此拯 救这唯一一株野生凤丹就只有克隆繁育一条路。但 是, 牡丹的组织培养至今尚未有成功的经验。因此 毫无疑问, 野生风丹处在极危 $(\mathrm{CR})$ 等级。

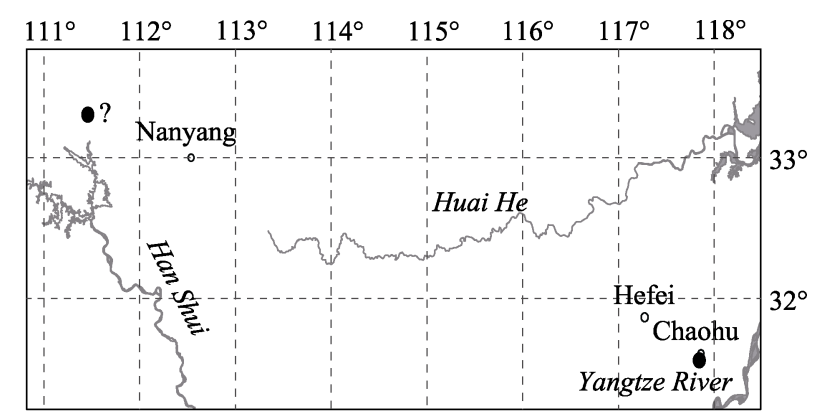

图8 凤丹野生植株分布点

Fig. 8 Distribution of wild populations of Paeonia ostii T. Hong \& J. X. Zhang

\section{(7)卵叶牡丹}

Paeonia qiui Y. L. Pei \& D. Y. Hong, Acta Phytotax. Sin. 33(1): 91. fig. 1. 1995.

异名: Paeonia ridleyi Z. L. Dai \& T. Hong, Bull. Bot. Res. Harbin 17 (1): 1. fig. 1.1997.

裴颜龙和洪德元依据邱均专1988年在湖北神
农架松柏镇对面的悬崖上采集的标本 (邱均专 PB88034)发表了这一物种。同年邱均专又在河南西 峡县采到标本，可惜标本记录仅有“西峡，1,600 m, 林下”。两年后又在与神农架相邻的保康县老雅山 长冲垭有了新的采集记录(即所谓的“红斑牡丹”P. ridleyi)。1997年我们在湖北保康县后坪镇的车丰坪 发现1个居群(图9a, b), 近年在陕西旬阳县的白柳镇

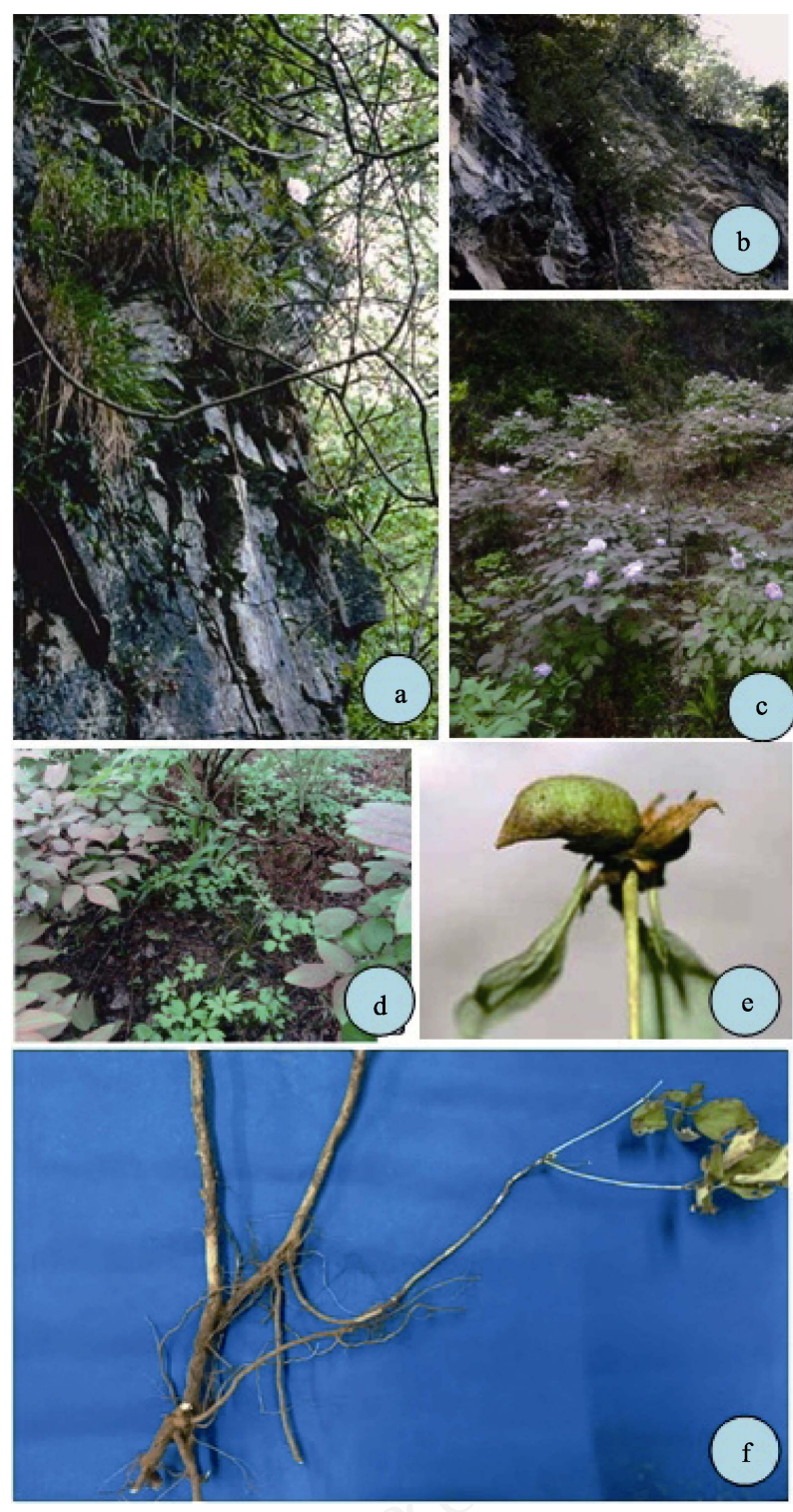

图9 卵叶牡丹。a, b: 湖北保康后坪镇车丰坪居群; c, d: 陕 西旬阳白柳镇居群; e, 湖北神农架山屯岩居群, 仅一个心皮 发育。f: 陕西旬阳白柳镇居群, 示根出条。c, d, f由张延龙 团队提供。

Fig. 9 Paeonia qiui Y. L. Pei \& D. Y. Hong. a, b, A population in Mt. Chefengping, Houping Township, Baokang, Hubei; c, d, A population in Bailiu Township, Xunyang, Shaanxi; e, A population in Mt. Shantunyan, Shennongjia, Hubei, showing only one carpel developed; f, The same population as c and d, showing suckering; c, d, f, From Yanlong Zhang's team. 
也发现了该物种的存在(图9c, d)。也就是说, 至今在 湖北和陕西一共发现 4 个卵叶牡丹产地, 其中河南 西峡的具体地点尚不确定。分布范围从北纬 $31^{\circ} 40^{\prime}$ 至 $33^{\circ} 20^{\prime}$, 东经 $109^{\circ} 20^{\prime}$ 至 $111^{\circ} 30^{\prime}$ (图10)。在垂直分布 上从 $1,300 \mathrm{~m}$ (保康后坪镇)至 $2,200 \mathrm{~m}$ (神农架)。因此, 无论从水平分布上还是垂直分布上, 卵叶牡丹都是 一个极其狭域的物种。根据对湖北神农架和保康以 及陕西旬阳的初步调查, 卵叶牡丹仅存 5 个居群, 个体数不超过 600 。这些居群大多见于稀疏落叶阔 叶林中, 有的见于林中悬崖上, 少见于灌从中。目 前, 卵叶牡丹最大的居群在陕西旬阳, 且多限于悬 崖上, 是过度采挖的剩余个体, 悬崖成了它们的避 难场所。卵叶告丹行有性繁殖和无性繁殖两种繁殖 策略。图9f显示, 陕西旬阳白柳镇居群中存在根出 条现象, 在神农架居群中亦观察到这种现象(附录 1d)。神农架和旬阳居群的结实率均很低, 其原因除 无性繁殖外, 还有可能是居群内个体过少而造成异 花传粉的成功率低下。这将可能导致居群进一步缩 小。由此看来, 卵叶牡丹应是濒危物种(EN)。

\section{(8)紫斑牡丹}

Paeonia rockii (S. G. Haw \& Lauener) T. Hong \& J. J. Li ex D. Y. Hong, Acta Phytotax. Sin. 37(6): 539. 1998.

异名: Paeonia suffruticosa Andrews subsp. rockii S. G. Haw \& Lauener; Paeonia papaveracea auct. non Andrews: 中国高等植物图鉴1：652. 图1303. 1972; Paeonia suffruticosa var. papaveracea auct. non Andrews: 中国植物志 27: 45. 图版3.1979。

紫斑牡丹包含两个亚种, 紫斑牡丹 (P. rockii subsp. rockii)和裂叶紫斑牡丹P. rockii subsp. atava (Brühl) D. Y. Hong \& K. Y. Pan。它们以秦岭为界, 南面是原亚种, 北面是裂叶紫斑牡丹。整个物种的 分布从北纬 $31^{\circ} 40^{\prime}$ 至 $36^{\circ} 45^{\prime}$, 东经 $104^{\circ}$ 至 $112^{\circ}$ (图11)。 其分布范围在 9 个野生牡丹物种中仅次于滇牡丹。 在垂直分布上从 $850 \mathrm{~m}$ 至 $2,800 \mathrm{~m}$, 跨度也仅次于滇 牡丹。从水平和垂直分布看, 紫斑牡丹应是一个正 常的物种。但其生态幅不大, 多见于落叶阔叶林下, 少见于林缘、灌从中(Hong, 2011b)。它全靠种子繁 殖, 至今尚未发现有地下茎或根出条现象。

根据对标本馆标本和自然居群的观察, 紫斑牡 丹 5 个心皮均发育为营䒿果, 败育胚珠也少。可见种

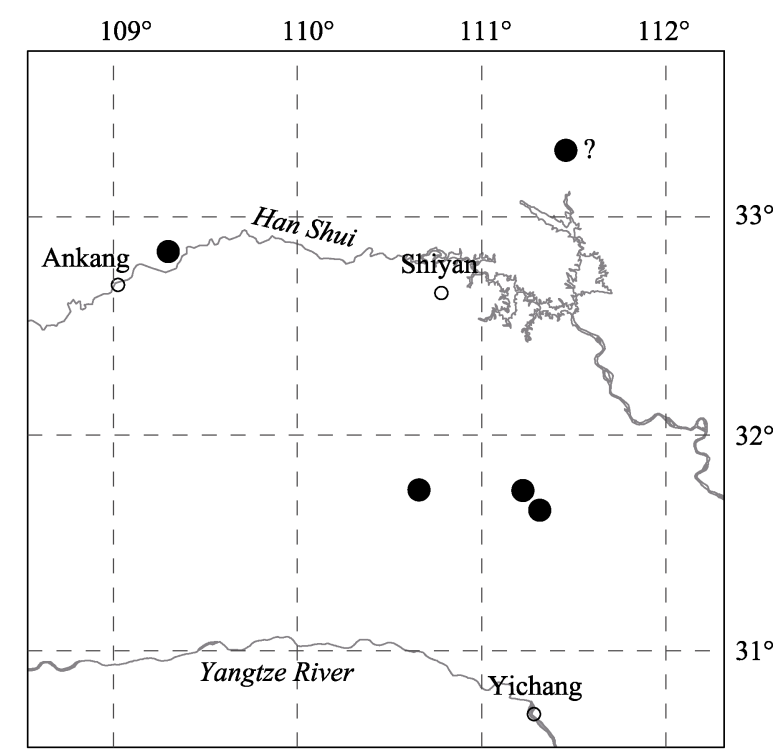

图10 卵叶牡丹野生居群的分布

Fig. 10 Distribution of wild populations of Paeonia qiui Y. L. Pei \& D. Y. Hong

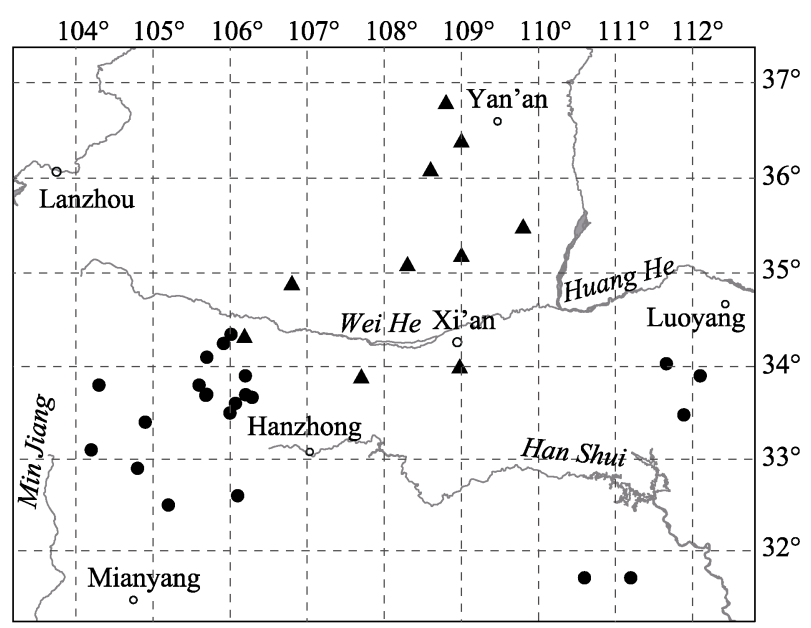

图11 紫斑牡丹野生居群的分布。圆形代表紫斑牡丹原亚种, 三角形代表裂叶紫斑牡丹。

Fig. 11 Distribution of wild populations of Paeonia rockii (S. G. Haw \& Lauener) T. Hong \& J. J. Li ex D. Y. Hong. Black circles: subsp. rockii; triangles: subsp. atava (Brühl) D. Y. Hong.

子繁殖是成功的。1960年以前, 紫斑牡丹相当常见, 特别是在秦岭, 包括太白山。但之后受到两次浩劫。 第一次是1960年和1961年的大量收购丹皮。如今我 们还未见到大的居群, 我们曾在太白山考察两天只 见到 3 株，一株在高高的悬崖上，一株在岩石之间， 还有一株是小苗。据当地药农介绍，1960年之前这 一带每天可挖上百斤鲜丹皮。第二次的浩劫则是随 着百姓生活水平的提高和休闲时间的增加, 乡村百 姓从山上移栽紫斑牡丹进自家庭院，正如我们在湖 
北保康和河南宝天曼见到的, 对野生紫斑牡丹造成 了严重威胁。对这种趋势如不采取果断措施予以遏 制, 不久的将来在山野里就再也难见这种最美野生 牡丹! 根据我们零星的调查和不完整的资料(附录 1e), 虽然野生紫斑牡丹的分布点 30 个以上(附录 1 : 表a), 但个体数不会超过 1,000 株, 且分布零星。更 令人遗憾的是, 野生紫斑牡丹的个体还在减少, 是 个濒危(EN)物种。

\section{(9)圆裂牡丹}

Paeonia rotundiloba (D. Y. Hong) D. Y. Hong, J. Syst. Evol. 49(5): 465, 2011.

异名: Paeonia decomposita Hand.-Mazz. subsp. rotundiloba D. Y. Hong, Kew Bull. 52(4): 961. fig. 1A. 1997.

圆裂牡丹最初被作为四川牡丹, 后来作为四川 牡丹的一个亚种(Hong, 1997a), 再后来的研究发现 它是独立的物种。其大多数个体心皮 3 , 而不是 5 ; 花盘包裹整个子房，而不是仅包着子房下半部; 小 叶数 (19-)25-37(-49), 而不是(35)37-63(-71); 顶生 小叶菱形至近圆形, 而不是粗圆形至狭菱形。这个 物种分布于岷江上游的黑水、理县、茂县、松潘和 汶川, 共10个居群, 即黑水的色尔古、理县城关的 大平、扑头乡的一棵印村和大沟口村; 茂县县城附 近、南新乡的文镇村、棉簇沟和黄草河; 松潘县的 镇江关和汶川县的龙溪乡, 分布范围从北纬 $31^{\circ} 20^{\prime}$ 至 $32^{\circ} 20^{\prime}$, 从东经 $103^{\circ}$ 至 $104^{\circ}$ (图12)。可以说, 圆裂 牡丹是一个非常狭域分布的物种。

对6个居群生态环境的调查显示, 它们生长于 海拔1,750-2,700 m, 5个生长于石灰岩地段, 另一个 生长于千枚岩土壤中(黑水县色尔古居群)。它们生 长于灌从、幼龄次生林和岷江柏(Cupressus chengiana)疏林(Hong, 2011b)。圆裂牡丹的生态幅比较狭 窄, 特别是从垂直高度和对土壤的要求上看。

根据我们的考察, 圆裂牡丹的生殖方式以种子 繁殖为主, 结实率较高。但是我们在黑水县色尔古 乡色尔古村的居群中发现了营养繁殖现象。一个植 株通过根出条长出至少7支茎, 从地面上看会被误 认为是 7 个独立的个体。这样的现象自然有利于个 体的保存和繁衍, 是延缓濒危和灭绝的潜在能力。 这种根出条现象在这个物种中是否普遍还有待进 一步调查。

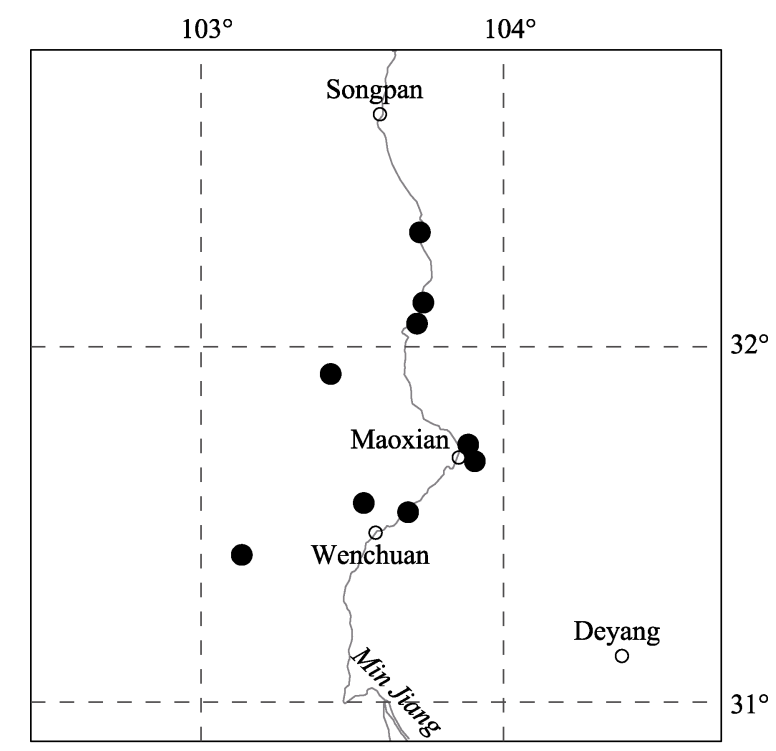

图12 圆裂牡丹野生居群的分布

Fig. 12 Distribution of wild populations of Paeonia rotundiloba (D. Y. Hong) D. Y. Hong

从我们的样方调查和访问老乡的情况来看, 这 个物种虽然分布区狭窄，生态幅很小，居群不多， 但个体数量并不很少。然而何兴金团队近年对黑水 色尔古、松潘镇江关、茂县棉簇沟和理县大沟口村 的调查表明, 这些居群的个体数分别约为 $95 、 62$ 、 13 和 20 株，总数仅约 190 株(何兴金，未发表资料)。 圆裂牡丹喜爱空旷的疏林和灌从，而在较密的次生 林和高灌从中开花的植株少，或虽开花但心皮败育 率高, 如在理县大平附近, 在高 $2 \mathrm{~m}$ 以上、盖度达 80-90\%的高灌从中, 仅少数植株开花结果。圆裂牡 丹受人为干扰很大，在调查前的一段时期(至少 10 年，即1985-1995年)，由于丹皮价格很低，采挖现 象不严重，居群得以恢复(附录1f)。由此看来，只要 不遭受滥采乱挖，即便狭域分布，圆裂牡丹还有生 存的机会。其居群内遗传多样性水平不高, 居群间 基因流水平较低, $\mathrm{N}_{\mathrm{m}}=0.8190$ (何兴金，未发表资 料), 是个濒危(EN)物种。

\section{5 讨论}

根据现有资料, 我们得到以下几点初步认识: (1)除滇牡丹外, 对其他野生牡丹生存状况的认识还 很肤浅。中原牡丹是否只剩杨老师宅旁那一株? 凤 丹是否真的只剩下安徽巢湖银屏山悬崖上那一 株？矮牡丹、四川牡丹、圆裂牡丹和大花黄牡丹的 分布和生存状况如何? 都有待进一步更深入的调 
查。对紫斑生丹和卵叶牡丹的生存状况认识的更是 不够。(2)野生的凤丹和中原牡丹正处于灭绝的边缘, 叒待抢救。(3)紫斑牡丹虽然分布颇为广泛, 但分布 零散, 且仅靠种子繁殖, 加之人为滥采乱挖, 处于 濒危状态，急需加强保护，严禁破坏野生居群。(4) 卵叶牡丹、四川牡丹和圆裂牡丹分布局限且零星, 受人为干扰严重, 属于濒危物种, 目前对它们的繁 殖行为还不够了解, 应加强科学研究, 力争解除其 濒危状态。(5)大花黄告丹和矮牡丹虽然分布很狭域, 但居群内个体较多, 如果能维持它们最适的生态环 境，应该可以保持现有的居群，应归于易危等级, 对这两个种的保护应是严禁采挖并创造适宜生境。

(6)滇牡丹的分布相对广泛, 适应能力较强, 又有无 性繁殖能力, 不属于濒危物种。滇牡丹的花色资源 异常丰富, 对那些稀少而珍贵的花色类型也应予以 保护。(7)在查明牡丹组各物种濒危状态、确定濒危 等级之后, 应开展解除其濒危状态的研究, 如查明 其最适环境、居群动态、遗传多样性、繁殖生物学 等, 在此基础上制定科学的保护策略, 采取切实有 效的解除濒危状态措施。

\section{6 建议}

牡丹是当之无愧的国花, 它的野生亲本应作为 国宝级自然资源予以保护。目前 9 个野生物种中有 8 个处于濒危状态，国家有关部门应尽快采取措施， 防止野生牡丹资源遭受新的浩劫。对 8 种处于濒危 状态的野生牡丹, 禁止任何形式的野生个体采挖。 严控企业和个人以建立资源(保护)戋的形式掠夺野 生资源。企业和个人不具备永久保护牡丹资源的条 件, 而且野生牡丹不同物种如果被引种到一起, 有 可能发生杂交, 造成混杂。因此, 当务之急需要对 牡丹野生物种进行全面、深入调查, 掌握确切信息, 制订科学的保护策略和切实可行的措施。同时, 开 展解除其濒危状态的保护生物学研究, 使其尽快摆 脱目前的濒危窘境，实现资源的可持续利用。

致谢: 这项工作涉及大量而艰苦的野外考察。首先 要感谢协助洪德元做了大量野外工作的河南农业 大学的叶永忠教授、王遂义教授、云南大学的虞泓 教授、中国科学院成都生物研究所的何永华博士、 西南大学的周志钦教授, 中国科学院植物研究所的
研究员潘开玉、王印政、罗毅波和朱相云，洪德元 过去的学生邱均专、裴颜龙、俸宇星, 以及许多帮 助过我们的朋友和老乡。在确定野生牡丹物种濒危 等级过程中, 我们得到植物所覃海宁研究员的热心 指点。李嘉玨先生和湖北保康县李洪喜先生, 植物 所的王亮生研究员、刘政安博士参加了今年2月在 中国科学院植物研究所举行的野生牡丹保护专家 座谈，贡献了他们的信息和建议。宫晓林负责稿 件的录入，宣晶协助绘制了分布地图，在此一并 感谢。

\section{参考文献}

APG (1998) An ordinal classification for the families of flowering plants. Annals of the Missouri Botanical Garden, 85, 531-553.

APG II (2003) An update of the Angiosperm Phylogeny Group classification for the orders and families of flowering plants: APG II. Botanical Journal of the Linnean Society, 141, 399-436.

APG III (2009) An update of the Angiosperm Phylogeny Group classification for the orders and families of flowering plants: APG III. Botanical Journal of the Linnean Society, 161, 105-121.

APG IV (2016) An update of the Angiosperm Phylogeny Group classification for the orders and families of flowering plants: APG IV. Botanical Journal of the Linnean Society, 181, 1-20.

Chase MW, Soltis DE, Olmstead RG, Morgan D, Les DH, Mishler BD, Duvall MR, Price RA, Hills HG, Qiu Y-L, Kron KA, Rettig JH, Conti E, Palmer JD, Manhart JR, Sytsma KJ, Michaels HJ, Kress WJ, Karol KG, Clark WD, Hedren M, Gaut BS, Jansen RK, Kim K-J, Wimpee CF, Smith JF, Furnier GR, Strauss SH, Xiang Q-Y, Plunkett GM, Soltis PS, Swensen SM, Williams SE, Gadek PA, Quinn CJ, Eguiarte LE, Golenberg E, Learn GH, Graham SW, Barrett SCH, Dayanandan S, Albert VA (1993) Phylogenetics of seed plants: an analysis of nucleotide sequences from the plastid gene $r b c \mathrm{~L}$. Annals of Missouri Botanical Garden, 80, 528-548, 550-580.

Cronquist A (1981) An Integrated System of Classification of Flowering Plants. Columbia University Press, New York.

Fu LK, Jin JM (1992) China Plant Red Data Book, Vol. 1: Rare and Endangered Plants. Science Press, Beijing. (in English) [傅立国, 金鉴明 (1991) 中国植物红皮书: 稀有濒危植 物(第一册). 科学出版社, 北京.]

Haw SG (2001a) Paeonia delavayi, a variable species. The New Plantsman, 8, 251-253.

Haw SG (2001b) Tree peonies: a review of their history and taxonomy. The New Plantsman, 8, 156-171.

Hong DY (1997a) Notes on Paeonia decomposita Hand. 
-Mazz. Kew Bulletin, 52, 957-963.

Hong DY (1997b) Paeonia (Paeoniaceae) in Xizang (Tibet). Novon, 7, 156-161.

Hong DY (2010) Peonies of the World: Taxonomy and Phytogeography, pp. 1-302. Royal Botanic Gardens Kew Publishing, Kew \& Missouri Botanical Garden Press, St. Louis.

Hong DY (2011b) Peonies of the World: Polymorphism and Diversity, pp. 1-96. Royal Botanic Gardens Kew Publishing, Kew \& Missouri Botanical Garden Press, St. Louis.

Hong DY (2011a) Paeonia rotundiloba (D. Y. Hong) D. Y. Hong: a new status in tree peonies (Paeoniaceae). Journal of Systematics and Evolution, 49, 464-467.

Hong DY, Pan KY (1999) Taxonomical history and revision of Paeonia sect. Moutan (Paeoniaceae). Acta Phytotaxonomica Sinica, 37, 351-368. (in Chinese with English abstract) [洪 德元, 潘开玉 (1999) 药药属牡丹组的分类历史和分类 处理. 植物分类学报, 37, 351-368.]

Hong DY, Pan KY (2007) Paeonia cathayana D. Y. Hong \& K. Y. Pan, a new tree peony, with revision of $P$. suffruticosa ssp. yinpingmudan. Acta Phytotaxonomica Sinica, 45, 285288.

Hong DY, Pan KY, Yu H (1998) Taxonomy of Paeonia delavayi complex (Paeoniaceae). Annals of Missouri Botanical Garden, 85, 554-564.

Jian SG, Soltis PS, Gitzendanner MA, Moore MJ, Li RQ, Hendry TA, Qiu YL, Dhingra A, Bell CD, Soltis DE (2008) Resolving an ancient, rapid radiation in Saxifragales. Systematic Biology, 57, 38-57.

Luo YB, Pei YL, Pan KY, Hong DY (1998) A study on pollination biology of Paeonia suffruticosa subsp. spontanea (Paeoniaceae). Acta Phytotaxonomica Sinica, 36, 134-144. (in Chinese with English abstract) [罗毅波, 裴颜龙, 潘开 玉, 洪德元 (1998) 矮牡丹 (Paeonia suffruticosa subsp. spontanea) (药药科)的传粉生物学研究. 植物分类学报,
36, 134-144.]

Pan KY (1979) Paeonia. In: Flora Reipublicae Popularis Sinicae, Tomus 27 (ed. Delectis Florae Reipublicae Popularis Sinicae Agendae Academicae Sinicae Edita), pp. 37-59. Science Press, Beijing. (in Chinese) [潘开玉 (1979) 䓎药 属. 见中国植物志: 毛茛科, 27卷, 37-59页. 科学出版社, 北京.]

Stern FC (1931) Peony species. Journal of Royal Horticultural Society, 56, 71-77.

Stern FC (1946) A Study of the Genus Paeonia, pp. viii + 155. The Royal Horticultural Society, London.

Stern FC, Taylor G (1951) A new peony from S. E. Tibet. Journal of Royal Horticultural Society, 76, 216-217.

Takhtajan AL (1987) System of Magnoliophyta. Academy of Sciences USSR, Leningrad.

Takhtajan AL (1997) Diversity and Classification of Flowering Plants. Columbia University Press, New York.

Yuan T, Wang LY (2003) Morphological studies on Paeonia sect. Moutan subsect Vagiatae in China. Acta Horticulturae Sinica, 30, 189-191. (in Chinese with English abstract) [袁 涛, 王莲英 (2003) 药药属牡丹组革质花盘亚组的形态 学研究. 园艺学报, 30, 189-191.]

Zhou SL, Hong DY, Pan KY (1999) Pollination biology of Paeonia jishanensis T. Hong \& W. Z. Zhao (Paeoniaceae), with special emphasis on pollen and stigma biology. Botanical Journal of the Linnean Society, 130, 43-52.

Zhou SL, Zou XH, Zhou ZQ, Liu J, Xu C, Yu J , Wang Q, Zhang DM, Wang XQ, Ge S, Sang T, Pan KY, Hong DY (2014) Multiple species of wild tree peonies gave rise to the "king of flowers" Paeonia suffruticosa Andrews. Proceedings of the Royal Society B: Biological Sciences, 281, 0141687. http://dx.orf/10.1098/rspb.2014.1687.

(责任编委: 葛学军 责任编辑: 周玉荣)

\section{附录 Supplementary Material}

\section{附录1 6种野生牡丹的调查材料}

Appendix 1 The information of six wild tree peony species from field explorations http://www.biodiversity-science.net/fileup/PDF/2017-129-1.pdf 
洪德元等. 野生牡丹的生存状况和保护. 生物多样性, 2017, 25 (7): 781-793.

http://www.biodiversity-science.net/CN/10.17520/biods.2017129

附录1 6种野生牡丹的调查材料

\section{Appendix 1 The information of six wild tree peony species from field explorations}

\section{a 四川牡丹(Paeonia decomposita Hand.-Mazz.) (洪德元团队, 1995, 2006年)}

四川金川县曾达乡曾达村, 海拔2,200-2,350 m, 西北坡, 多石灰石悬崖和岩石。密而高达 $2-3 \mathrm{~m}$ 的 灌 从, 建 群 种有 Sageretia sp., Cotoneaster soongaricus, Buxus sp., Zanthoxylum sp., Osteomeles sp., Ouercus aff. giliana, Bauhimia sp., Lespedeza sp.。 局部可见50株以上，但有花的仅有 10 株，其中有几 株很大, 但也只有单朵花。向导谷林先生告诉我们, 20 世纪 80 年代, 这里每天可挖 $30 \mathrm{~kg}$ 丹皮, 那时的野 生牡丹几乎连成片。

金川绰斯甲(红旗桥与观音桥之间), 海拔 2,400-2,500 m, 北坡, 变质石灰岩, 次生柏树林和 高灌从, 灌木主要有Abelia sp.和Lespedeza sp.。四川 牡丹局部多见, 幼苗不下 50 株, 但开花的少。林中及 高灌从中开花的个体少见, 且每株仅有单朵花或两 朵。但在岩石上的稀疏灌从中发育较好, 见3株, 每 株有十几朵花, 且心皮多数发育, 种子多。

马尔康附近, 有 4 个地点, 海拔2,650-3,100 m, 都在灌从中。以城附近的南坡居群为例, 高 $2-2.5 \mathrm{~m}$ 的多刺灌丛，占优势的成分为Quercus semecarpifolia, Cotoneaster soongaricus, Rhamnus sp., Berberis sp., Rosa willmottiae 等。充分发育的心皮少, 多数很小就 败育。在城附近的阿底村, 海拔2,700 m, Betula-Picea 林缘疏灌从中, 生长良好, 每株有花10朵以上, 前一 年的结实情况也很好(图2 c-e)。

丹巴县东谷乡沙冲沟, 海拔 $2,350 \mathrm{~m}$, 东北坡, 石 灰岩, 幼龄次生林, 优势成分为Carpinus sp., Aralia sp., Acer sp., Pittospermum sp., Senecio sp., Lespedeza $\mathrm{sp}$. 等。四川牡丹见于树木稀疏的岩石边, 在 $10 \mathrm{~m}^{2}$ 的 一片次生林中见到30株, 植株大但花不多。

在考察的路上我们多处询问老乡关于当地四川 牡丹的情况。在马尔康梭磨乡(海拔 $2,900 \mathrm{~m}$ ), 在金 川县白湾乡和独松乡, 在丹巴县的小金区和康定县 的孔玉乡, 得到的回答都是有四川牡丹, 而且有些 地方还颇为常见(如独松乡)。丹巴县药材公司收购 站周琳先生告诉我们, 全县有野生生丹, 但量不大。 当时最低收购价仅 2 元 $/ \mathrm{kg}$ 。

b 矮牡丹(Paeonia jishanensis T. Hong \& W. Z. Zhao) (洪德元团队, 1993, 1994)
山西永济雪花山水峪口村，北坡，从海拔970 m 到1,650 m均有。生境从开旷的灌从至颇为郁闭的次 生落叶阔叶林(图 $5 \mathrm{~b}, \mathrm{c}$ )。在海拔 $1,300 \mathrm{~m}$ 的地段, 伴生 植物主要有 Quercus baronii, Exochorda giraldii, Forsythia suspensa, Zanthoxylum sp., Deutzia sp., Clematis sp., Vitis sp., Lonicera sp., Adenophora sp., Carex sp., Corydalis sp.等。在海拔 1,650 m的阔叶林中, 主要乔木有Carpinus turczaninowii和Tilia amurensis。 在这个居群内我们观察到地下横走茎, 而且很普遍, 一条这样的茎可发出多条地上茎(图5d)。

山西稷山马家沟居群分两个地段作观察。一个 在村附近靠公路不远处, 海拔 $1,100 \mathrm{~m}$ 群落为次生幼 林 (图 5a), 常见的伴生植物有 Quercus baronii, Exochorda giraldii, Cotinus coggygria, Forthythia suspensa, Elaeagnus mollis, Rosa dahurica, Adenophora sp., Clematis sp.和Carex sp.等。我们试 图找到实生苗, 但挖了几次都是连着较大植株的萌 生苗。另一个地段在海拔 $1,700 \mathrm{~m}$ 处, 常见的伴生植 物 有 Quercus aliena, Crataegus kasuensis, Campylotropis macrocarpa, Forsythia suspensa, Melampyrum roseum, Atractylodes lancea, Phlomis umbrosa, Dianthus chinensis, Bupleurum chinense 等。

我们观察过1959年采自甘肃兰州兴隆山 2,400 $\mathrm{m}$ 处的标本 $(\mathrm{PE})$ 。此标本无生境记录, 应该不是自然 的。还观察了1959年采自陕西户县的标本 (PE), 无 具体地点, 亦无海拔和生境记录, 应该是栽培的。

在马家沟村听老乡(包括我们住的东家赵大爷) 介绍, 1961年前后这里大量收购丹皮, 矮牡丹几乎 被挖尽。现在看到的都是后来长出来的, 近些年老 乡们不再挖丹皮是因为价格较低。

\section{c 大黄花牡丹 [Paeonia ludlowii (Stern \& G.} Taylor) D. Y. Hong] (洪德元团队: 1996, 2006, 2017)

西藏米林岗嘎大桥东3-4 km处(江北岸): 疏林 和灌从中, 成优势种, $50 \mathrm{~m} \times 30 \mathrm{~m}$ 样方中约有 100 株 (成年), 成丛, 实生苗极多, 上一年结的果极多(图 6d, f)。伴生植物有Juglans sp., Populus sp., Salix sp., Prunus davidiana, Rhamnus (2 spp.), Rosa sp., Berberis sp., Artemisia sp., Pteridium sp.。盖度50\%。 2017年调查发现基本情况变化不大, 估计植株总数 约 800 。 
洪德元等. 野生牡丹的生存状况和保护. 生物多样性, 2017, 25 (7): 781-793.

http://www.biodiversity-science.net/CN/10.17520/biods.2017129

米林岗嘎大桥西 $2 \mathrm{~km}$ 处, 扎热乡, 才母村, 扇 形冲积物上(图6a, c)。伴生植物有Juglans sp., Prunus davidiana, Pyrus sp., Hippophae sp., Rhamnus sp., Berberis sp., Buddleja sp., Cotoneaster sp., Morus sp., Clematis sp., Senecio sp., Thalictrum sp.。花岗岩, $2,980 \mathrm{~m}$, 面积约 $500 \mathrm{~m} \times 500 \mathrm{~m}$, 实生苗多, 幼株亦 极多, 盖度60\%, 挖出7株, 全为实生苗(图6e)。大的 植株高可达 $3.5 \mathrm{~m}$, 有花达105朵。2017年的实地调查 发现, 这里已开辟了高等级公路, 拉萨至林芝的铁 路正在施工, 工区就设在这里, 加上新建了许多民 房, 环境大变。我们未能找到一个植株。

米林热嘎村附近, 大桥西约 $6 \mathrm{~km}$, 江南岸北坡 山脚, 小沟边, 3,000 m, 花岗岩, Picea砍伐迹地, 盖 度 $20 \%$ 。伴生植物有Picea sp., Pteridium sp., Iris sp., Acer sp., Ribes sp., Salix sp., Betula sp., Rosa sp., Sambucus sp., Rhododendron sp., Berberis sp., Sorbaria sp. 面积约 $400 \mathrm{~m} \times 250 \mathrm{~m}$ 。植株密, 成优势 种, 实生苗极多。取丹皮破坏严重, 挖起的植株无数, 高达 $3.5 \mathrm{~m}$, 茎下部直径达 $3 \mathrm{~cm}$ (图6b)。2017年的实 地调查发现, 这一居群未有大的变化, 约有 5,000 株, 是现存最大的居群。但它现在被圈在Hilton酒店之 内, 坚有“黄牡丹保护区”牌子。这一中文学名是错 的; 保护区归属尚不明确, 故其前景令人担忧。

米林南伊乡南伊沟, $2,920 \mathrm{~m}$, 花岗岩, 沟口阶 地, 稀树疏灌丛, Rosa疏灌从。大花黄告丹多见, 相 当密集, 有许多被挖取丹皮。米林县贸易公司夏经 理介绍: “前几年收购丹皮, 最多一年收购 3,000 斤 (鲜重)。如今售价不好。”2017年再次造访时发现, 这 一很大居群的 $2 / 3$ 已被开发, 被住房和高档酒店占 据, 仅发现一株残留的大黄花牡丹。在边防站以上 的 $1 / 3$ 还保存完好。在 $1 \mathrm{~km}$ 长的路两边灌从中约有 2,000株, 其中很多幼株, 繁殖状况不错。

隆子加玉乡淮巴达拉山，3,150 m, 山坡灌从, 1972年记录。2017年调查发现, 该居群很小, 仅24 株 (9 成株, 15 幼株)。在一株约 $5 \mathrm{~m}$ 高的沙棘 (Hippophae sp.)树下，3株成年个体下面无一幼苗, 足见遮阴是种子萌发的障碍。

隆子斗玉乡加麦 (?)(Charme, Char Chu), $28^{\circ} 26^{\prime} \mathrm{N}, 93^{\circ} 05^{\prime} \mathrm{E}, 3320 \mathrm{~m}, 1938$ 记录。

林芝东久乡曲尼玛村, 3,100 m, 山脚扇形地。仅 有4株, 2 大 2 小, 老乡说是自然的, Larix sp., Berberis sp., Ribes (2 spp.), Rosa (2 spp.), Iris sp., Primula sp., Podophyllum sp., Lonicera sp.。果极多, 但未发现完 好的果实。2017年调查表明, 原有的植株已被移栽
至家门口。一位老乡说, 这些植株本是从林芝移来 的。因此东久乡并无自然居群。

西藏农牧学院(林芝八一镇)院内有一块种植的 大花黄牡丹, 其生存和繁殖状况良好。

1936和1938年, Ludlow等3位英国采集家把大 花黄牡丹引到英国, 如今英国至少有两处种有该种, 即伦敦的英国自然博物馆大门前两侧(图6g)和皇家 邱植物园(Royal Botanic Gardens, Kew)。王强博士的 来信(个人交流)说, 两处均结实, 种子饱满(图6h); 英国自然博物馆植物部主任Sandra Knapp称, 英国 多地种有这个物种, 繁殖状况良好。

\section{d 卵叶牡丹(Paeonia qiui Y. L. Pei \& D. Y. Hong) (洪德元团队, 1997, 2004; 张延龙团队, 2014-2016)}

湖北保康县后坪镇车丰坪, 海拔 $1,300 \mathrm{~m}$, 东坡, 石灰岩, 次生落叶阔叶林。乔木层主要有: Quercus sp., Acer sp., Carpinus sp.; 灌木层由Carpinus sp., Platycarya strobilacea, Lindera sp., Rhamnus sp., Spiraea sp., Lonicera sp.等组成。卵叶牡丹个体不多, 约 15 株, 大多在高数米至数十米的悬崖上。

湖北神农架松柏镇山屯岩, 海拔 1,900-2,200 m, 见于落叶阔叶林下的悬崖上和草地中。发现有两朵 花结出的果实, 一朵 5 个心皮仅 3 个结出蓇菅果, 每 个有种子 1 或 2 粒。另一朵花的 5 个心皮仅一个发育成 为蓇菅果, 其中有种子 3 粒(图9 e)。

根据我们1997年的调查, 保康县后坪镇的老乡 喜爱在宅前屋后种植从山上挖来的野生牡丹。例如 在洪家院村, 舒远志家前院就种有一株紫斑牡丹和 数株卵叶牡丹, 主人说都是近年从附近山上挖来 的。此外还有许多其间的杂种后代的幼苗。同村的 祁新华家门前也种有紫斑牡丹和卵叶牡丹, 其中一 株杂种就是所谓“保康牡丹”(Paeonia baokangensis) 的模式标本来源。所谓的“保康牡丹”其实就是紫斑 牡丹与卵叶牡丹的杂种Paeonia rockii $\times$ qiui。

陕西旬阳县白柳镇峰溪村, 海拔 $1,456 \mathrm{~m}$, 疏林 下或林缘灌丛，伴生植物主要有：Sabina chinensis, Pinus bungeana, Quercus variabilis, Cotinus coggygria, Lonicera meackii, Akebia trifoliata, Bupleum chinense, Aconitum carmichaeli等。多数个 体在疏林下, 少数植株见于岩石缝中。有幼苗(实生 苗?), 看来更新不错。

旬阳县白柳镇居群有个体约 300 。有无性繁殖现 象, 结实率低, 但结实率与群落的郁闭度相关, 郁 闭度越低, 结实率越高。 
洪德元等. 野生牡丹的生存状况和保护. 生物多样性, 2017, 25 (7): 781-793.

http://www.biodiversity-science.net/CN/10.17520/biods.2017129

e 紫斑牡丹[Paeonia rockii (S. G. Haw \& Lauener)

T. Hong \& J. J. Li ex D. Y. Hong] (1939, 1985, 1994, 1997, 2006)

嵩县木植街乡石磙坪居群。1994年我们分两路 寻找野生牡丹凤丹(“杨山牡丹”)和紫斑牡丹。野生 的“杨山牡丹”未找到, 两路都找到了紫斑牡丹。海 拔1,450 m左右, 花岗岩, Ulmus幼林。星散可见, 但 不多, 两队各见到数株, 在大岩石下。

河南内乡县宝天曼自然保护区牡丹垛居群。海 拔 $1,100 \mathrm{~m}$, 东南坡, 玄武岩, 落叶阔叶林, 一个很 小的居群, 10株, 开花的仅两株。这是一个残存并在 恢复中的居群。山下的村里的宅旁种有挖自山上的 紫斑牡丹。

\begin{tabular}{|c|c|c|}
\hline & $\begin{array}{l}\text { 居群大小 } \\
\text { (株) } \\
\end{array}$ & 调查队和年份 \\
\hline \multicolumn{3}{|l|}{ subsp. rockii } \\
\hline \multicolumn{3}{|l|}{ 河南 } \\
\hline 内乡: 宝天曼 & 约 20 & 洪德元, 1997; 袁军辉 \\
\hline 栾川: 熊耳山 & $20-30$ & 袁军辉 \\
\hline 嵩山: 杨山 & $<20$ & 洪德元等, 1994 \\
\hline \multicolumn{3}{|l|}{ 湖北 } \\
\hline 保康: 后坪镇 & 6 & 袁军辉 \\
\hline 保康: 大水林场 & 约 20 & 袁军辉, 李洪喜, 2017 \\
\hline 神农架(松柏) & $<50$ & 洪德元, 2004 \\
\hline \multicolumn{3}{|l|}{ 陕西(南) } \\
\hline \multicolumn{3}{|l|}{ 略阳: 白水江 } \\
\hline \multicolumn{3}{|l|}{ 甘肃(东南) } \\
\hline 徽县: 麻沿河 & $<50$ & 袁军辉, 2007 \\
\hline 龙骨粱 & 约 80 & 袁军辉, 2008 \\
\hline 嘉陵镇 & $<100$ & 袁军辉, 2008 \\
\hline \multicolumn{3}{|l|}{ 银杏乡 } \\
\hline 成县: 王磨乡 & $<20$ & 袁军辉, 2007 \\
\hline 鸡峰山 & 6 & 移栽? \\
\hline 二郎乡 & 6 & 移栽? \\
\hline 两当: 张家乡 & $<80$ & 袁军辉, 2008 \\
\hline 文县: 刘家坪 & 约 100 & 袁军辉 \\
\hline \multicolumn{3}{|l|}{ 舟曲: 洮州林场 } \\
\hline \multicolumn{3}{|l|}{ 武都：朗山 } \\
\hline \multicolumn{3}{|l|}{$\begin{array}{l}\text { 天水: 李子乡 } \\
\text { 李子村 }\end{array}$} \\
\hline 子陇山 & & 黄河队, 1956 \\
\hline \multicolumn{3}{|l|}{ 四川(北部) } \\
\hline \multicolumn{3}{|l|}{ 广元：曾家 } \\
\hline \multicolumn{3}{|l|}{ 南坪: 双河 } \\
\hline \multicolumn{3}{|l|}{ 青川: 龚龙(?) } \\
\hline \multicolumn{3}{|l|}{ subsp. atava } \\
\hline \multicolumn{3}{|l|}{ 甘肃(东南、东部) } \\
\hline 天水: 党川 & $<100$ & 袁军辉, 2007, 2008, 2014 \\
\hline
\end{tabular}

\begin{tabular}{lll}
\hline 合水: 太白镇 & 约100 & 袁军辉, 2008-2016 \\
陕西 & & \\
太白山 & 少到难以 & 洪德元等, 1985, 1997; 袁 \\
& 发现 & 军辉, 2009, 2014, 2015 \\
旬邑 & $20-30$ & 袁军辉, 2014, 2015 \\
甘泉: 下寺湾 & $<100$ & 洪德元等, 2006; 袁军辉, \\
陇县: & & 2008 \\
南五台: & \\
铜川: 金锁 & & \\
志丹: 志丹墓 & & \\
黄龙山: 白城桥 & & \\
\hline
\end{tabular}

秦岭南五台山古湾柏树附近, 1939年5月14日。 刘慎谔、钟补求等127(PE)的标本记录签上有一个附 注, “这是栽培生丹的野生类型, 在秦岭湿润的林中 常见……”

陕西甘泉县下寺湾乡, 海拔 $1,320 \mathrm{~m}$, 砂岩, 辽 东栋(Quercus)-白桦(Betula)-槭树(Acer)林, 在一片 不大的林中, 有约 20 株。其中多数花瓣白色, 少数红 色。向导张先生说有 2,000-3,000株。我们未作大范 围调查。

秦岭太白山上白云, $1,750 \mathrm{~m}$, 栋树林中, 岩石 中间。仅 1 株, 也是我们在太白山考察两天发现的 3 株之一(图9b)。一位挖药的老乡说, 1960年以前这一 带每天可挖上百斤鲜丹皮。我们发现的这一株附近 无小苗, 或许是因为岩石间种子不宜扎根生长, 这 一株之所以还存在或许是因为不易采挖而幸免。

\section{f 圆裂牡丹[Paeonia rotundiloba (D. Y. Hong) D. Y. Hong] (洪德元团队, 1995, 1996, 2006)}

四川黑水县色尔古居群，东北坡，海拔 $2,300 \mathrm{~m}$, 千枚岩(变质石灰岩), 高度可达 2-4 $\mathrm{m}$ 的高灌从, 盖 度 70-90\%, 主要伴生植物有Quercus sp., Rhamnus sp., Sophora sp., Cotoneaster sp., Rosa sp., Lonicera 2 spp., Euonymus sp.等。居群内个体颇多, 在 $20 \mathrm{~m} \times 15$ $\mathrm{m}$ 样方内的植株不下 40 , 估计会有成百上千个体。最 大个体有花超20朵。存在根出条现象, 一条根长出 至少7支茎。

理县朴头乡居群, 海拔 1,850-2,280 m, 北坡, 石灰岩, 多岩石山坡或悬崖, 疏林中, 以Cupressus chengiana和Quercus sp. 为优势, 或灌从中, 幼苗多, $60 \mathrm{~m} \times 20 \mathrm{~m}$ 内见到上百株, 多在苔藓层上。岩石上 多见。心皮极少败育。

理县城附近大平村, 海拔1,900-1,950 m, 西北 坡, 石灰岩, 高达 $2 \mathrm{~m}$ 以上的高而密的灌从, 盖度 80-90\%, 主要伴生植物有Quercus 2 spp., Ostryopsis 
洪德元等. 野生牡丹的生存状况和保护. 生物多样性, 2017, 25 (7): 781-793.

http://www.biodiversity-science.net/CN/10.17520/biods.2017129

davidiana, Cotinus coggygria, Cotoneaster sp., Lespedeza sp.等。有很多个体, 但仅4株有果。

茂县太平乡沙湾, 海拔 $2,350 \mathrm{~m}$, 悬崖灌从。个 体多, 结实率颇高, 仅个别心皮败育。

茂县城北, 海拔 $2,100 \mathrm{~m}$, 阳坡灌从, 靠近悬崖。 在13朵中，仅一个心皮败育。

茂县城东北 $5 \mathrm{~km}$ 处生态站下, 海拔 $1,750 \mathrm{~m}$, 东坡,
石灰岩灌从, Ostryopsis sp., Quercus 2 spp., Cotinus coggygria, Corylus sp., Rosa multibracteata, Cotoneaster sp., Spiraea sp.等。调查6个植株, 近一半心皮败育。

在黑水色尔古乡, 理县扑头乡和沙坝乡, 老乡 们都说当地野生牡丹普遍, 近年多起来, 因为丹皮 便宜, 每公斤仅一元多。 